\title{
SOCIO-DEMOGRAPHIC FACTORS AND SELF-HEALING OF PAIN PHENOMENON IN POLAND
}

\section{CZYNNIKI SOCJODEMOGRAFICZNE A ZJAWISKO SAMOLECZENIA BÓLU W POLSCE}

\author{
${ }^{1}$ Department of Public Health, Medical University of Warsaw \\ 1a Banacha St., 02-097 Warsaw, Poland
}

S u m mary

Introduction. Self-healing applies to the use of non-prescription drugs, as well as nutritional supplements, and herbal plant products for the treatment of diseases and symptoms diagnosed single-handedly.

The aim of this study is to evaluate the impact of socio-demographic factors on the phenomenon of selfhealing pain among Poles.

Material and method. The study involved 218 randomly selected respondents, 159 women and 59 men. The tool was a questionnaire designed for the study. Collected data were analyzed using cross tables.

Results. During six months before the start of the study $90 \%$ of respondents used the analgesics. Women declared that they took pain medication several times a month, three times more often than men. The type of pain for which respondents most frequently used the self-treatment is varied by gender as well as age and type of professional activity of the studied group. The most important factor in the purchase of the drug among the oldest patients is usually the pharmacist's advice ( $47.1 \%$ of the group), and among the youngest respondents - previous use of the drug $(62.5 \%)$. About $70 \%$ of respondents admit that they use the Internet to obtain information about medicines.

Conclusions. The most important element in the development of responsible self-treatment is education, in terms of both responsible consumption of analgesics, and the use of appropriate sources concerning the treatment of these diseases.

\section{Streszczenie}

Wprowadzenie. Samoleczenie dotyczy głównie stosowania leków wydawanych bez recepty, ale również suplementów diety, produktów roślinnych i ziół w leczeniu chorób oraz objawów rozpoznanych samodzielnie.

C e le m p r a c y jest ocena wpływu czynników socjodemograficznych na zjawisko samoleczenia bólu przez Polaków.

Materiał i metoda. W badaniu udział wzięło 218 losowo wybranych respondentów, 159 kobiet oraz 59 mężczyzn. Narzędzie stanowił kwestionariusz skonstruowany na potrzeby badania. Zabrane dane poddano analizie tabelarycznej z wykorzystaniem tabel krzyżowych.

Wyniki. W okresie sześciu miesięcy przed rozpoczęciem badania po leki przeciwbólowe sięgnęło $90 \%$ ankietowanych. Kobiety trzykrotnie częściej niż mężczyźni

Key words: self-healing, pain, medicinal product Stowa kluczowe: samoleczenie, ból, produkt leczniczy deklarowały, że zażywały leki przeciwbólowe kilka razy w miesiącu. Rodzaj dolegliwości bólowych, w przypadku których respondenci najczęściej stosowali samoleczenie jest zróżnicowany ze względu na płeć, jak również wiek oraz rodzaj aktywności zawodowej badanych. Czynnikiem skłaniającym do zakupu leku przez najstarszych pacjentów jest najczęściej porada farmaceuty (47,1\% grupy), a dla najmłodszych - wcześniejsze zastosowanie leku (62,5\%). Około $70 \%$ badanych przyznaje, że wykorzystuje internet do pozyskania informacji o lekach.

W nioski. Najistotniejszym elementem rozwoju odpowiedzialnego samoleczenia jest edukacja, zarówno w zakresie odpowiedzialnej konsumpcji leków przeciwbólowych, jak również w zakresie wykorzystywania odpowiednich źródeł dotyczących terapii tych dolegliwości. 


\section{INTRODUCTION}

An idea of self-healing promotion developed based on Alma Ata declaration which was introduced by the World Health Assembly in 1978, putting on the first place an intention of using its potential for building effective health systems. Moving part of responsibility for his own health onto patient, became day to day factor of international health policy. Over the years engagement of patient into therapeutic process has taken brand new forms and the 'self-medication' term was established in medicine, understood as drug selfestate. This phenomenon concerns not only using medicines given out without prescription, but also diet supplements, plant products and herbs in treatment of self-diagnosed diseases and symptoms which, according to the World Health Organization's definition, in practise means also healing by the family members or friends. In view of this definition selfhealing is often connected with an omission of getting doctor's opinion during the therapeutic process. Although, according to the WHO correctly practised self-healing leads to the rise of people's health level and, what comes afterwards, to improvement of health quality. Benefits for health care system are mainly related to reducing the number of visits in the health care facilities - coming from resignation of medical advice by patients with common health issues, in case of which it is possible to diagnose the issue and propose a proper use by themselves. This brings with itself measurable benefits for patients suffering from chronic diseases who need permanent medical supervision, for whom the founds for specialized health care rise.

Development and scale of this phenomenon in certain countries are conditioned in huge part by cultural, socio-economic factors or legal regulations. We have been able to observe this phenomenon in Poland for last two decades and still it characterises with a high dynamic. In comparison to 90's of the last century when the usage of drugs available without prescription in case of disease was declared by about $10 \%$ Polish people, now they are used by almost everyone. The most popular group are painkillers, drugs dealing with symptoms of cold and flu and diet supplements. OTC drugs are now available outside the pharmacies and it is also legal to advertise them in media. In effect, a percentage of people buying drugs outside the pharmacies increases, sources of getting information about the drugs are changing too. More and more Polish people admit that the knowledge about fighting the sickness symptoms comes from the Internet and that they use this knowledge while buying medicines. It leads to going away from the idea proclaimed by WHO, according to which the properly practised self-healing should be based on the professional pharmaceutical care.

This study shows the influence of sociodemographic factors onto the phenomenon of pain selfhealing. Independent therapy of pain symptoms was put under analysis. Research led in Poland show that pain is the most commonly felt somatic symptom among Poles. As the report "Social Diagnosis 2011" shows, to the group of the most often complaints staying for at least half a month we could include: neck and shoulders pain or tension, whole body pains, strong headaches and stomach-aches. Relatively frequently people complained on fatigue not related to the current job and rapid blood pressure jumps. Rising phenomenon was decided to be watched closer in 2009 in the study on health of Polish people organized by the Main Statistical Office (GUS) submitting in the questionnaire for the first time the question about feeling pain and physical discomfort among people at the age of 15 and older. The study was concentrated on symptoms observed during 4 weeks before the study, taking under consideration the length and intensity of the symptoms. Within over 28 million tested Poles, $56.5 \%$ admitted that during analysed time they felt pain or physical discomfort considered by most of them as mild or slight.

The pattern of analgesics consumption, including safety of self-therapy and the most often sources of information about painkillers, was shown in the study.

\section{PURPOSE OF THE RESEARCH}

The main purpose of this research is the impact assessment of socio-demographic factors on the phenomenon of pain self-healing among Polish.

\section{MATERIAL AND METHODS}

Research material includes data collected by the questionnaire constructed particularly for this study. The questionnaire contained 23 multiple choice questions of which 17 were questions about OTC painkillers using. The study was performed in May 
2013 within random chosen citizens of Warsaw and Łowicz.

Finally, 218 random chosen respondents took part in the study. 159 women and 59 men. The highest percentage of respondents were young people between 18 and 24 years $(44 \%)$ and the smallest part were people between 55 and 64 years $(5 \%)$. Every $5^{\text {th }}$ respondent was a person between 25 and 34 years old and persons between 35 and 44 years made $10.6 \%$ of the whole group. $12.4 \%$ of all respondents were people between 45 and 54 years. The oldest people - over 65 years old made $7.8 \%$ of the tested population. Nearly half of all respondents were pupils and students $45.9 \%$. Blue and white collar workers made respectively $25.2 \%$ and $19.3 \%$. Every tenth respondent who took part in the study was a retired person. Over a half of respondents were people with secondary education $(59.6 \%)$. The rest of respondents were people with higher education $(21.1 \%)$ and vocational education (19.3\%).

To show dependents between independent variables (socio-economic) and chosen dependent variables tabular analysis with cross tables was used. Data collected during the research were developed in SPSS programme. Statistic measures used in the result interpretation were number of occurrence of response and percentage of the whole group. Differences between variables were verified by Chi2 Pearson's test with the statistical significance factor $\mathrm{p}<0.05$.

\section{RESULTS}

Before asking the questions about drug consumption patterns, respondents were asked to express an opinion on the safety of self-therapy with analgesics, which are available without a prescription. About $60 \%$ of the respondents see the risks associated with using analgesics, while only $15.6 \%$ of the respondents expressed their firm belief in the negative effects of these drugs on the body.

Respondents were asked to determine the frequency of use of painkillers available without a prescription during the 6 months prior to the survey. 90\% of respondents reached for analgesics during the analyzed period. Nearly half of the respondents used the selfmedication sporadically, 1 - 2 times during the period, $36.7 \%$ applied analgesics several times a month, while $5.5 \%$ had been taking these products several times a week. A major factor differentiating the frequency of drug use was the gender of the respondent $(p<0.05)$.
Women three times more often than men declared that they were taking analgesics several times a month (44.7\%). Men more often reached for drugs occasionally, 1-2 times during the analyzed period $(66.1 \%)$.

The most common ailments for which respondents reached for OTC medicines were headaches (44\%) and menstrual pains $(31.2 \%)$. For nearly one in ten of respondents, pain most often forcing to reach for an analgesics were back pain $(9.2 \%)$, and musculoskeletal disorders $(8.3 \%)$. Other ailments, indicated by respondents were also toothaches, pain associated with injuries and pain occurring in the course of a cold or flu. However, the percentage of these responses was low, amounted $3.7 \%$ for tooth pain and $1.8 \%$ for both pain associated with injuries as well as the common cold or flu. Type of pain for which respondents most frequently used the self-treatment varied by gender as well as by age and type of professional activity of respondents (in both cases $\mathrm{p}<0.05$ ). Among the answers given by the women, the most common were headaches and migraines $(49.1 \%)$ and menstrual pains $(42.8 \%)$. Men most often reach for painkillers for the headache (one in three men). High percentage in this group of patients use non-prescription analgesics to control back pain and musculoskeletal problems, respectively, $25.4 \%$ and $23.3 \%$. Due to the age of the respondents some differences among answers of respondents in age between 18 and 44 and of respondents aged over 44 years may be noted. People between 18 and 44 years turned to analgesics mainly due to headaches and menstrual pains. In older age groups, headache ceases to be the dominant complaint, while respondents indicated back pain and musculoskeletal disorders as the most common cause for self-medication. Back pain and musculoskeletal problems were also the most frequently indicated by blue-collar workers and retirees. Aside from menstrual pains, which existence is not related to the type of work, white-collar workers are taking analgesics most often to combat headaches or migraine $(59.5 \%)$. Such a response has also been granted by half of students participating in the survey.

In the next question, respondents were asked to identify the most frequently used active ingredient. Two answers were dominant: ibuprofen, designated as the active substance most commonly used by $42.2 \%$ of respondents, and paracetamol, indicated by $41.3 \%$ of respondents. Other used substances were metamizol $(4.6 \%)$ and naproxen $(3.7 \%)$. Slightly more than $8 \%$ of 
the respondents claimed that they did not pay attention to the active substance in the used analgesic. This response was characteristic for men. In case of the most frequently used active substance, analysis shows a significant correlation between the age of the respondent and the type of substance $(p<0.05)$ : ibuprofen was the substance used mainly by young people. Older people, especially the respondents above 65 years old, in order to relieve pain were taking medicines that contain paracetamol (88.2\%).

Further issues analyzed in the study were: the factor inducing to purchase pain medication, place of purchasing painkillers and source of information about the drug.

According to $54.1 \%$ of the respondents, their purchase decisions are mostly affected by earlier experiences with using the drug. About $18 \%$ of the respondents are directed primarily with the advice of family or friends. Thus, in most cases, respondents choose already tested drug and, in their or a close relative's opinion, effective. Less than $1 \%$ pointed advertisement as an important factor when choosing a drug. The study shows that the pharmacist's advice influences the buyer's decisions in only $16.6 \%$ of respondents, while consultation with the doctor influences every tenth respondent.

Public pharmacies and pharmacy points are still the main places of purchasing drugs. About $75 \%$ of respondents declared buying medicines in these places. Others use the services of online pharmacies $(2.8 \%)$ or purchase drugs on the non-pharmacy market $(22.9 \%)$.

Despite the fact that $75 \%$ of respondents purchase analgesics without a prescription at pharmacies or pharmacy points, for less than $20 \%$ of them the pharmacist is the most important source of information about the drug. The majority of respondents $(60.1 \%)$ obtains information primarily from the leaflet supplied to the drug. For $8.3 \%$ of the respondents a doctor is the main source of information on OTC pain medication. Every tenth respondent pointed media advertisements as the primary source of information. About $2 \%$ indicated also the website information.

Analysis of the survey results indicated that there is a correlation between the age of the respondent and the issues raised above $(\mathrm{p}<0.05)$. Among the oldest, over 55 years old, the pharmacist's advice is important while choosing the right product $(47.1 \%)$. Moreover, people over 65 years old indicated also medical advice as an important factor $(23.5 \%)$. For respondents over 65 years the pharmacists and doctors are also primary sources of information about painkillers. This group also reported the highest percentage of people who buy drugs in pharmacies or pharmacy points $(100 \%)$. For the youngest respondents a driving force for selecting a specific medicine was mainly earlier usage of the drug. This response was indicated by $62.5 \%$ of the respondents between 18 and 24 years old and $68.2 \%$ of respondents between 25 and 34 years old.

Analysis of the survey results shows that the gender of the respondent is important for the factors determining the choice of drug $(\mathrm{p}<0.05)$. Proven efficiency is important for women, that is why the main factor affecting their purchasing decision is earlier usage of the drug $(64.8 \%)$. Men are most often guided by the advice of family or friends (40.7\%), although one in four men also declared reaching for the previously tried medicine. For men, the pharmacist is also an important source of information about the drug. That response was indicated by $33.9 \%$ of men and only by $13.8 \%$ of women. Women more likely obtain knowledge from the drug leaflets $(67.9 \%)$ this is confirmed by answers to questions about the safety of the drug.

In the next part of the survey, respondents were asked to indicate whether they use referring to the drug information leaflet and whether they follow its recommendations.

Approximately $98 \%$ of respondents declared that they use the leaflet that comes with the medicine. Every twenty-tested person does that. Slightly more than half examines the content of leaflet when the drug is unknown for them and they use it for the first time. About $24 \%$ of people use leaflets only when looking for specific information about the drug. As mentioned above, the analysis of the study made it possible to see significant differences in the use of information leaflet connected with the gender of the respondent $(p<0.05)$. Every fourth tested woman always reads the leaflet, about $60 \%$ whenever the drug is unknown to them and they use it for the first time, only $13.2 \%$ said they only reaches a leaflet when looking for specific information about medicine.

Among male respondents answers were different. Only $6.8 \%$ of men use leaflet every time. Every third man became acquainted with the leaflet while using new, unknown drug. More than half of men (52.5\%) admitted that the leaflet is a source of knowledge about the drug in rare situations. However, $6.8 \%$ of men do not use the information contained in this leaflet. In addition, men also often admit that sometimes they do 
not apply the dosage $(20.3 \%$ of men and $5 \%$ of women). More often than women they also admit that they used analgesic despite contraindication to use and that they happen to take on-prescription painkillers for more than five days.

In the next section, respondents were asked to express their opinion on the pain that they feel should be seen as a health hazard. Respondents were to indicate the duration of the pain, which, in the opinion of the respondents, should be consulted with the doctor. For the vast majority of respondents a worrying signal, inducing to consult with a doctor, is a pain that lasts longer than a few days, despite the use of analgesics $(68.8 \%)$. Every twentieth respondent considers worrying pain lasting for several weeks, every tenth - pain lasting for twenty four hours. Men more often than women indicated that a disturbing signal inducing a consultation with a doctor is pain that lasts longer than a few weeks, the response indicated by $35.6 \%$ of men and $14.5 \%$ women. This answer was also characteristic for the oldest respondents. As many as $82.4 \%$ of respondents over 65 years indicated as worrying pain lasting more than a few weeks. Most of the remaining respondents indicated mainly the answer 'pain lasting more than a few days'. Respondents were also asked whether they ever gave up on medical advice despite heightened pain. Resignation was the case for $12.8 \%$ of the respondents. About $80 \%$ declared that such situation never happened. Resignation of medical consult in case of persisting symptoms was characteristic especially for young people between 18 and 24 years old.

Further, the questionnaire included a question related to the use of the Internet as a source of information about pain and its treatment. About $70 \%$ of respondents admit that they use the Internet to obtain related information, while $50 \%$ do so occasionally, and $18.3 \%$ have done it many times. To the question 'In the case of pain do you use the Internet to search information / advice?' answer 'Yes, often' was mostly granted by young people aged 18-24 and 25-34 years. People between 34 and 45 years old use the Internet as a source of information about the pain, but they do it occasionally.

Most of the older respondents do not use the Internet for this purpose, and $100 \%$ of respondent over age 65 never does. Analyzing the question from the point of the professional activity of respondents, except for retirees who do not benefit from this source of information, the highest percentage of respondents declaring that they are looking for online information about pain was observed among blue-collar workers, where the answer was given by almost every second respondent. One in three white-collar worker, and every fourth student repeatedly used the Internet as a source of information about pain and its treatment.

\section{CONCLUSIONS}

Self-healing of pain is a commonly occurring phenomenon in Polish society. Poles often use drugs available without prescription, and the pharmacy is no longer the only place to purchase them. Non-pharmacy market is expanding quickly, and thus, the availability of medicines in general stores, in drugstores and at gas stations increases. Poles began to perceive drugs as other products available at these sites. This is confirmed by the analysis of the survey, the results of which clearly indicate that as many as one in four respondents do not see the threat of self-healing with painkillers. In the study group there were people who have admitted that they do not always comply with the recommendations for the dosage of the drug, as well as those who use analgesics, even though there are contraindications for using them. Worrying seems to be a trend of using the Internet as a source of information about pain and its treatment, occurring among the youngest respondents, which is [9]. This means that they take advantage of the available scientific articles in the network, but they can also often hit at various forums where users exchange experiences. Use of this type of information can cause wrong self-diagnosis, use of improper treatment and, more importantly, increase the time to avoid medical consultation, which in some cases can affect the development of the disease. It seems that the most important element in the development of responsible self-medication is education [10], both in terms of responsible consumption of analgesics, but also in the use of appropriate sources of information about treatments of these diseases, which can be a challenge for public health experts.

\section{REFERENCES}

1. WHO: Guidelines for the Regulatory Assessment of Medicinal Products for Use in Self-Medication. http://apps.who.int/medicinedocs/pdf/s2218e/s2218e.pdf (access: 2013.09.22). 
2. Kasperczyk J., Jośko J., Klimasara J. i in..: Zjawisko samoleczenia wśród studentów wybranych kierunków. Problemy Higieny i Epidemiologii 2007, 88(2): 206-207.

3. Krajewska Kułak E., Ortman E., Moczydlowska A. i in.: Radzenie sobie $\mathrm{z}$ dolegliwościami w drodze samoleczenia w populacji studentów Uniwersytetu Medycznego w Białymstoku. Problemy Higieny i Epidemiologii 2011, 92(3): 496.

4. TNS OBOP: Co robi chory Polak? Warszawa 1996, http://obop-arch.tnsglobal.pl/archive-report/id/569 (access: 2013.09.22).

5. Ulatowska-Szostak E.: Wpływ reklamy na zakup leków, parafarmaceutyków i preparatów witaminowych w opiniach klientów aptek - porównanie lat 2002 i 2007. Problemy Higieny i Epidemiologii 2008, 89(3):441-442.

6. Skonieczna A.: Polacy często sięgają po leki OTC i suplementy diety. http://www.pmrcorporate.com/ (access: 2013.09.22).

7. Diagnoza Społeczna 2011. Czapiński J., Panek T. (red.). Warszawa

2011 , http://www.diagnoza.com/pliki/raporty/Diagnoza_raport _2011.pdf (access: 2013.09.22).

8. Główny Urząd Statystyczny: Stan zdrowia ludności Polski w 2009 r.. Warszawa 2011, http://www.stat.gov.pl/cps/rde/xbcr/gus/ZO_stan_zdrowi a_2009.pdf (access: 2013.09.22).
9. Ulatowska-Szostak E., Marcinkowski J.T., GromadeckaSutkiewicz M. i in..: Badania nad Internetem jako źródłem informacji o chorobie. Problemy Higieny i Epidemiologii 2009, 90(2): 253.

10. Ulatowska-Szostak E., Marcinkowski J.T., GromadeckaSutkiewicz M. i in.: Badania nad Internetem jako źródłem informacji o chorobie. Problemy Higieny i Epidemiologii 2008, 89(2): 270.

Address for correspondence:

Aleksandra Czerw, PhD

Medical University of Warsaw

Department of Public Health

1a Banacha St.

02-097 Warsaw

tel.: 225992180

e-mail: ola_czerw@wp.pl

Received: 25.04.2014

Accepted for publication: 26.08.2014 